\title{
Methylopila capsulata gen. nov., sp. nov., a novel non-pigmented aerobic facultatively methylotrophic bacterium
}

\author{
Nina V. Doronina, ${ }^{1}$ Yuri A. Trotsenko, ${ }^{1}$ Valentina I. Krausova, ${ }^{1}$ \\ Eugenia S. Boulygina ${ }^{2}$ and Tatjana P. Tourova ${ }^{2}$
}

\begin{abstract}
Author for correspondence: Yuri A. Trotsenko. Tel: +795925 74 48. Fax: + 7959233602. e-mail: trotsenko(aibpm.serpukhov.su
\end{abstract}

\footnotetext{
1 Institute of Biochemistry and Physiology of Microorganisms, Russian Academy of Sciences, Pushchino, Moscow region, 142292, Russia

2 Institute of Microbiology, Russian Academy of Sciences, Moscow, 117811, Russia
}

\begin{abstract}
A new genus, Methylopila, and one new species are described for a group of seven strains of facultatively methylotrophic bacteria with the serine pathway of $C_{1}$ assimilation. These bacteria are aerobic, Gram-negative, non-sporeforming, motile, colourless rods that multiply by binary fission. Their DNA base content ranges from 66 to $70 \mathrm{~mol} \% \mathrm{G}+\mathrm{C}$. Their cellular fatty acid profile consists primarily of $C_{18: 1 u}$ cis-vaccenic and $C_{19: 0}$ cyclopropane acids. The major hydroxy acid is $3-\mathrm{OH} \mathrm{C}_{14: 0}$. The main ubiquinone is $\mathrm{Q}-10$. The dominant cellular phospholipids are phosphatidylethanolamine and phosphatidylcholine. The new isolates have a low level of DNA-DNA homology (5-10\%) with the type strains of the serine pathway methylobacteria belonging to the genera Methylobacterium, Aminobacter, Hyphomicrobium and Methylorhabdus. Another approach, involving 165 rRNA gene sequence analysis of strain IM1', has shown that the new isolates represent a separate branch within the $\alpha-2$ subclass of the Proteobacteria. The type species of the new genus is Methylopila capsulata sp. nov., with the type strain IM1' (= VKM B-1606').
\end{abstract}

Keywords: serine pathway methylotrophs, Methylopila capsulata gen. nov., sp. nov.

\section{INTRODUCTION}

The group of aerobic Gram-negative asporogenous facultatively methylotrophic bacteria (methylobacteria) having the serine pathway and capable of growth on a variety of reduced $C_{1}$ substrates, except methane. is very heterogeneous. However, so far only four of the previously described genera have been validly published: Hyphomicrobium, Methylobacterium, Aminobacter and Methylorhabdus. As known, the representatives of the genus Hyphomicrobium form hyphae and multiply by budding (Hirsch, 1984), the genus Methylobacterium was emended for the pink-pigmented facultative methylobacteria (PPFM) (Patt et al., 1976; Bousfield \& Green, 1985). The genus Aminobacter was proposed for nonpigmented, budding, methylamine-utilizing bacteria unable to grow on methanol (Urakami et al., 1992) and the new genus Methylorhabdus was suggested for

Abbreviations: PMS, phenazine methosulfate; PPFM, pink-pigmented facultative methylobacteria.

The GenBank accession number for 16S rDNA sequence for Methylopila capsulata $\mid \mathrm{M} 1^{\top}$ is AF004844. colourless non-motile dichloromethane-utilizing bacteria (Doronina et al., 1995). Nevertheless, it seemed evident that a taxonomic structure of the serine pathway facultative methylobacteria should include some new taxa to cover their phenotypic and genotypic diversity. Previously, we described three novel strains of colourless facultative methylobacteria having an intermediate position between the genera Methylobacterium and Aminobacter and proposed the generic name Methylomicrobium for these strains (Govorukhina et al., 1989; Doronina \& Trotsenko, 1992). Since the genus 'Methylomicrobium' (Govorukhina et al., 1989) has not been validated, this generic name was subsequently used for a group of Type I methanotrophs (Bowman et al., 1995). In view of the fact that our extended study of "Methylomicrobium capsulatus' (Govorukhina et al., 1989) showed that this organism did not belong to the genus Methylomicrobium (Bowman et al., 1995) it would be appropriate to place this organism in a new genus, for which we propose the name Methylopila. Our studies of seven non-pigmented strains of facultatively methylotrophic bacteria which utilize the serine pathway indicate that they should be placed in a single 
species, for which we propose the name Methylopila capsulata.

\section{METHODS}

Bacterial strains. Pure cultures of seven bacterial strains (IM1 ${ }^{\mathrm{T}}$, UZ, 14, 9AA, 10AA, 26AA and 37AA) utilizing methanol and methylamine as well as some multicarbon compounds as growth substrates were isolated from soil samples taken from Uzbekistan (IM1 $\left.{ }^{\mathrm{T}}, 14, \mathrm{UZ}\right)$ and Kazakhstan (AA) as described earlier (Govorukhina et al., 1989; Doronina \& Trotsenko, 1992). Methylobacterium organophilum XX ATCC $27886^{\top}$ was kindly supplied by R. S. Hanson (University of Minnesota, USA). K. Komagata (Tokyo University, Japan) provided Protomonas strains (Urakami \& Komagata, 1984) that have been reclassified later into the genus Methylobacterium (Bousfield \& Green, 1985) as Methylobacterium extorquens NCIB 9399" (= TK $0001^{\mathrm{T}}$ ) and Methylobacterium rhodesianum NCIB 10611 (= TK 0016). Hyphomicrobium zavarzinii IFAM ZV-622 $2^{\mathrm{T}}$ was obtained from G. A. Zavarzin (Institute of Microbiology, Moscow, Russia). Aminobacter aminovorans ATCC $23314^{\mathrm{T}}$ $\left(=\mathrm{JCM} 7852^{\mathrm{T}}=\mathrm{NCIB} 9039^{\mathrm{T}}\right)$, Aminobacter aminovorans ATCC 23819 (strain MA = NCIB 11590) (Urakami et al., 1992), Methylorhabdus multivorans ATCC $51890^{\mathrm{T}}$ (strain $\mathrm{DM} 13^{\mathrm{T}}=\mathrm{VKM} \quad \mathrm{B}-2030^{\mathrm{T}}$ ) and Pseudomonas aeruginosa ATCC $10145^{\mathrm{T}}$ were used as the reference strains.

The methylotrophic cultures were grown on a liquid mineral medium $\mathrm{K}$, containing $2.0 \mathrm{~g}\left(\mathrm{NH}_{4}\right)_{2} \mathrm{SO}_{4}, 2.0 \mathrm{~g} \mathrm{KH}_{2} \mathrm{PO}_{4}, 0.5 \mathrm{~g}$ $\mathrm{NaCl}, 0 \cdot 125 \mathrm{~g} \mathrm{MgSO}_{4} .7 \mathrm{H}_{2} \mathrm{O}, 0.002 \mathrm{~g} \mathrm{FeSO}_{4} .7 \mathrm{H}_{2} \mathrm{O}$, and 11 distilled water; the $\mathrm{pH}$ of this medium was adjusted to $7 \cdot 2$. Substrates were sterilized and added separately. Methanol or methylamine were added to a concentration of $0.5 \%$ $(\mathrm{v} / \mathrm{v})$ or $0.3 \%(\mathrm{w} / \mathrm{v})$, respectively. Flasks were shaken at $29^{\circ} \mathrm{C}$. Pseudomonas aeruginosa was grown with $0 \cdot 3 \%(\mathrm{w} / \mathrm{v})$ glucose. The bacterial strains were maintained on medium $\mathrm{K}$ solidified with Difco Bacto agar or PYG agar $(\mathrm{pH} 7 \cdot 0)$ (Urakami et al., 1992).

Identification methods. Cell morphology, Gram staining, motility and flagellation were determined by using the cultures grown on solid medium $\mathrm{K}$. Production of a fluorescent pigment was tested on King A and B agarized media. Nitrate reduction was tested in liquid medium $\mathrm{K}$ in which $\left(\mathrm{NH}_{4}\right)_{2} \mathrm{SO}_{4}$ was replaced with $0.5 \%(\mathrm{w} / \mathrm{v}) \mathrm{KNO}_{3}$ after 1,3 and $5 \mathrm{~d}$ incubation. The methyl red and Voges Proskauer (acetoin) reactions were tested in glucose/ phosphate/peptone broth. Indole production was determined with Kovacs' reagent in $1 \%$ Tryptone broth. Hydrogen sulfide production was tested on triple-sugar iron agar for 2 weeks. Gelatin hydrolysis was observed in stab cultures in yeast extract-peptone medium containing $12 \%$ gelatin after 4 weeks incubation at $22{ }^{\circ} \mathrm{C}$. Starch hydrolysis was determined by using an iodine solution on medium $\mathrm{K}$ agar containing $0.2 \%$ soluble starch after 1,3 and $10 \mathrm{~d}$ incubation.

Ammonia production was tested in peptone water by Nessler's reagent. Oxidase activity test was performed with a $1 \%$ solution of tetramethyl-p-phenylenediamine dihydrochloride. Urease activity was observed on Christensen's medium. Catalase activity was detected by pouring a $3 \%$ $\mathrm{H}_{2} \mathrm{O}_{2}$ solution into colonies on solid medium $\mathrm{K}$ or $\mathrm{PYG}$ agar. Halotolerance was tested by inoculating the cells into liquid medium $\mathrm{K}$ with various concentrations of $\mathrm{NaCl}$ $(1-3 \%)$. Growth at different temperatures and $\mathrm{pH}$ values were tested in liquid medium $\mathrm{K}$. Utilization of a wide range of growth substrates $(>50)$ was also determined in liquid medium $\mathrm{K}$ after 2 weeks cultivation with methanol being replaced by the other carbon compounds. Organic acids and amino acids were added at concentrations of $0.05-0.3 \%$, while carbohydrates and alcohols were added at concentrations of $0.2-0.5 \%$. To test alternative nitrogen sources $\left(\mathrm{NH}_{4}\right)_{2} \mathrm{SO}_{4}$ was replaced by the other nitrogen compounds.

Methane utilization was tested in an atmosphere containing $\mathrm{CH}_{4}$ and air $(1: 1, \mathrm{v} / \mathrm{v})$ in $700 \mathrm{ml}$ conical flasks containing $100 \mathrm{ml}$ medium $\mathrm{K}$ and fitted with rubber stoppers. Hydrogen utilization was tested by the same procedure but in an atmosphere of $\mathrm{H}_{2}+\mathrm{O}_{2}+\mathrm{CO}_{2}(7: 2: 1$, by vol.). Utilization of mono- and dichloromethane was tested as described earlier (Doronina et al., 1995). Liquid cultures were grown at $30{ }^{\circ} \mathrm{C}$ on a rotary shaker at 180 r.p.m.

Phospholipid and cellular fatty acid composition. Phospholipid composition of the cells was determined according to the methods described previously (Govorukhina \& Trotsenko, 1989). To determine the cellular fatty acid composition the cultures were grown on methanol or methylamine with $2 \%$ agar medium $\mathrm{K}$ on Petri plates for $48 \mathrm{~h}$ at $29^{\circ} \mathrm{C}$. Several milligrams of cells were transferred with a loop to a screw-top microreaction jar containing $150 \mu 1$ of a $20 \%$ aqueous tetramethylammonium hydroxide solution, the mixture was heated at $100^{\circ} \mathrm{C}$ for $20 \mathrm{~min}$ and cooled to room temperature, and $100 \mu \mathrm{l}$ of acetonitrile was added. The jar was shaken, $20 \mu \mathrm{l}$ of the top (acetonitrile) layer was withdrawn and evaporated in a stream of nitrogen at room temperature, $20 \mu \mathrm{l} 20 \%$ tetramethylammonium hydroxide solution was added, the mixture was heated at $100^{\circ} \mathrm{C}$ for $1 \mathrm{~min}$, and a $0 \cdot 2-0 \cdot 5 \mu \mathrm{l}$ portion was introduced into the chromatograph injector (heated to $385^{\circ} \mathrm{C}$ ). The analysis was carried out in a Hewlett-Packard 5830A chromatograph, using a $15 \mathrm{~m} \times 0.2 \mathrm{~mm}$ glass capillary column filled with silicone OV-101 sorbent.

Poly- $\beta$-hydroxybutyrate was analysed according to Braunegg et al. (1978) by using a Pye Unicam 104 gas chromatograph. Ubiquinones were extracted and purified according to Collins (1985). Their analysis was done by using a Finnigan MX-1310 mass spectrometer. Enzyme assays were done as previously described (Meiberg \& Harder, 1978; Trotsenko et al., 1986; Doronina et al., 1995).

Electron microscopic analysis. To obtain thin sections, bacterial cells were fixed for $1 \mathrm{~h}$ at $4{ }^{\circ} \mathrm{C}$ in $0.05 \mathrm{M}$ sodium cacodylate buffer $(\mathrm{pH} 7 \cdot 2)$ containing $1.2 \%(\mathrm{v} / \mathrm{v})$ glutaraldehyde, washed three times in the same buffer and refixed in $1 \%(\mathrm{w} / \mathrm{v}) \mathrm{OsO}_{4}$ in $0.05 \mathrm{M}$ cacodylate buffer for $4 \mathrm{~h}$ at $4{ }^{\circ} \mathrm{C}$. After dehydration in a series of alcohols, the cells were embedded in Spurr epoxy resin and sectioned with an LKB 2128 Ultratome. The thin sections were stained with $1 \%$ uranyl acetate and then with $2 \%$ lead citrate for $10 \mathrm{~min}$ and mounted on copper grids. To obtain negatively contrasted preparations, the cells were stained in $0.3 \%(\mathrm{w} / \mathrm{v})$ phosphotungstic acid ( $\mathrm{pH} 7 \cdot 2$ ). Micrographs were taken with a JEM $100 \mathrm{~B}$ transmission electron microscope at an operating voltage of $60 \mathrm{kV}$.

DNA isolation and characterization. DNA was isolated and purified according to Marmur (1961). DNA G $+C$ contents were determined by the thermal denaturation method with a Beckman DU-8B spectrophotometer at a heating rate of $0.5^{\circ} \mathrm{C} \mathrm{m^{-1 }}$ and were calculated according to Owen \& Lapage (1976). The DNA from Escherichia coli K-12 was used as the standard. DNA-DNA hybridization was done on nitrocellulose membrane filters $(0.22 \mu \mathrm{m})$ at optimal conditions (incubation in $50 \%$ formamide at $50{ }^{\circ} \mathrm{C}$ for $24 \mathrm{~h}$ with the use of deoxy $\left[1^{\prime}, 2^{\prime}, 5^{\prime}-{ }^{3} \mathrm{H}\right] \mathrm{CTP}$ and the nick trans- 
lation kit N 5500 (Amersham) as described earlier (Doronina et al., 1987).

16S rDNA sequence determination and analysis. Genomic DNA was extracted and the $16 \mathrm{~S}$ rRNA gene was selectively amplified by PCR, using the following primers: $5^{\prime}-A G A G-$ TTTGATCCTGGCTCAG-3' as forward and 5'-TACGGTTACCTTGTTACGACTT-3' as the reverse (Lane, 1991). The PCR reaction was carried out in a final volume of $100 \mu \mathrm{l}$, with $1 \mu \mathrm{g}$ DNA template, $200 \mu \mathrm{M}$ each primer, $200 \mu \mathrm{M}$ each dNTP, $3 \mathrm{U}$ Tet-z polymerase (BioMaster,

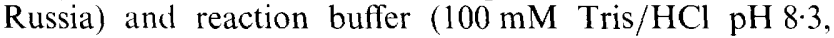
$500 \mathrm{mM} \mathrm{KCl}, 2 \mathrm{mM} \mathrm{MgCl}_{2}$ ). The temperature cycling was done by using 30 cycles of the following thermal profile: $1 \mathrm{~min}$ at $94{ }^{\circ} \mathrm{C}, 1 \mathrm{~min}$ at $42^{\circ} \mathrm{C}, 1 \mathrm{~min}$ at $72^{\circ} \mathrm{C}$. The final extension was carried out at $72^{\circ} \mathrm{C}$ for $6 \mathrm{~min}$. The PCR products were purified using the PCR-prep kit (Promega) according to the manufacturer's instructions. The $16 \mathrm{~S}$ rRNA gene was sequenced in both directions with the use of forward and reverse primers listed by Lane (1991). DNA sequencing was carried out by using Sequenase version 2 of the VSB kit (USB) with minor modifications.

Phylogenetic analysis. The sequence of strain $\mathrm{IM} 1^{\mathrm{T}}$ was aligned manually with sequences obtained from the database of small subunit rRNAs (Larsen et al., 1993). The sequence was compared with members of the Proteobacteria: Methylomicrobium agile ACM 3308 ${ }^{\mathrm{T}}$, X72767; Methylococcus capsulatus Texas ${ }^{\mathrm{T}}$, X72770; Methylobacter luteus VKM-53B ${ }^{\mathrm{T}}$. M95657; Methylomonas methanica ACM $3307^{\mathrm{T}}$, RDP 653; Methylophaga marina ATCC $35842^{\mathrm{T}}$, X87338; Pseudomonas aeruginosa ATCC 25330, M34133; Methylophilus methylotrophus NCIB 10515 , L15475; Methylobacillus glycogenes ATCC $29475^{\mathrm{T}}$, M95652; Rhodobacter sphueroides IFO 12203, D16425; Paracoccus denitrificans LMG 4218 ${ }^{\mathrm{T}}$, X69159; Hyphomicrobium vulgare ATCC 27500, X53182; Methylosinus trichosporium OB3b ${ }^{\mathrm{T}}$, M29024; Methylocystis parvus OBBP ${ }^{\mathrm{T}}$, M29026; Rhodopseudomonas viridis ATCC 19567, D25314; Blastobacter denitrificans LMG 8443, X66025; Methylobacterium organophilum NCIMB 11278 ${ }^{\mathrm{T}}$, D32226; Xanthobacter agilis SA35, D16425; Blastobacter capsulatus ATCC 43294, X73042; Brucella abortus 11/19, X13695; Acidomonas methanolica IMET 10945 $5^{\mathrm{T}}$, D30770; Bosea thiooxidans BI-42 ${ }^{\mathrm{T}}$, X81044; Ancylobacter aquaticus DSM 101 ${ }^{\mathrm{T}}$, M27803; Thiobacillus novellus IAM 12100, D32247; and Bacillus subtilis 168, $\mathrm{X} 00007$, as outgroup. Regions that were either not sequenced in one or more reference organisms or had alignment uncertainty, i.e. positions 1-45, 70-100, 183-218, $451-480,998-11048$ and $1376-3^{\prime}$ terminus (E. coli nomenclature) were omitted from the analyses, so in total 1078 nucleotides were used in the analysis. Pairwise evolutionary distances (expressed as estimated changes per 100 nucleotides) were computed by use of the correction of Jukes \& Cantor (1969). A tentative unrooted phylogenetic tree was constructed by using a 'maximum topological similarity' algorithm (Chumakov \& Yushmanov, 1988) and the program TREE of the GENEBEE package (Brodsky et al., 1991). The rooted-by-outgroup phylogenetic tree was constructed by the neighbour-joining method (Saitou \& Nei, 1987) with bootstrap analysis of 100 trees and using the TREECON package programs (Van de Peer \& De Wachter, 1994).

\section{RESULTS}

\section{Morphology}

The bacterial isolates were represented by Gramnegative, asporogenous, colourless rods $(0 \cdot 5-0 \cdot 7) \times$
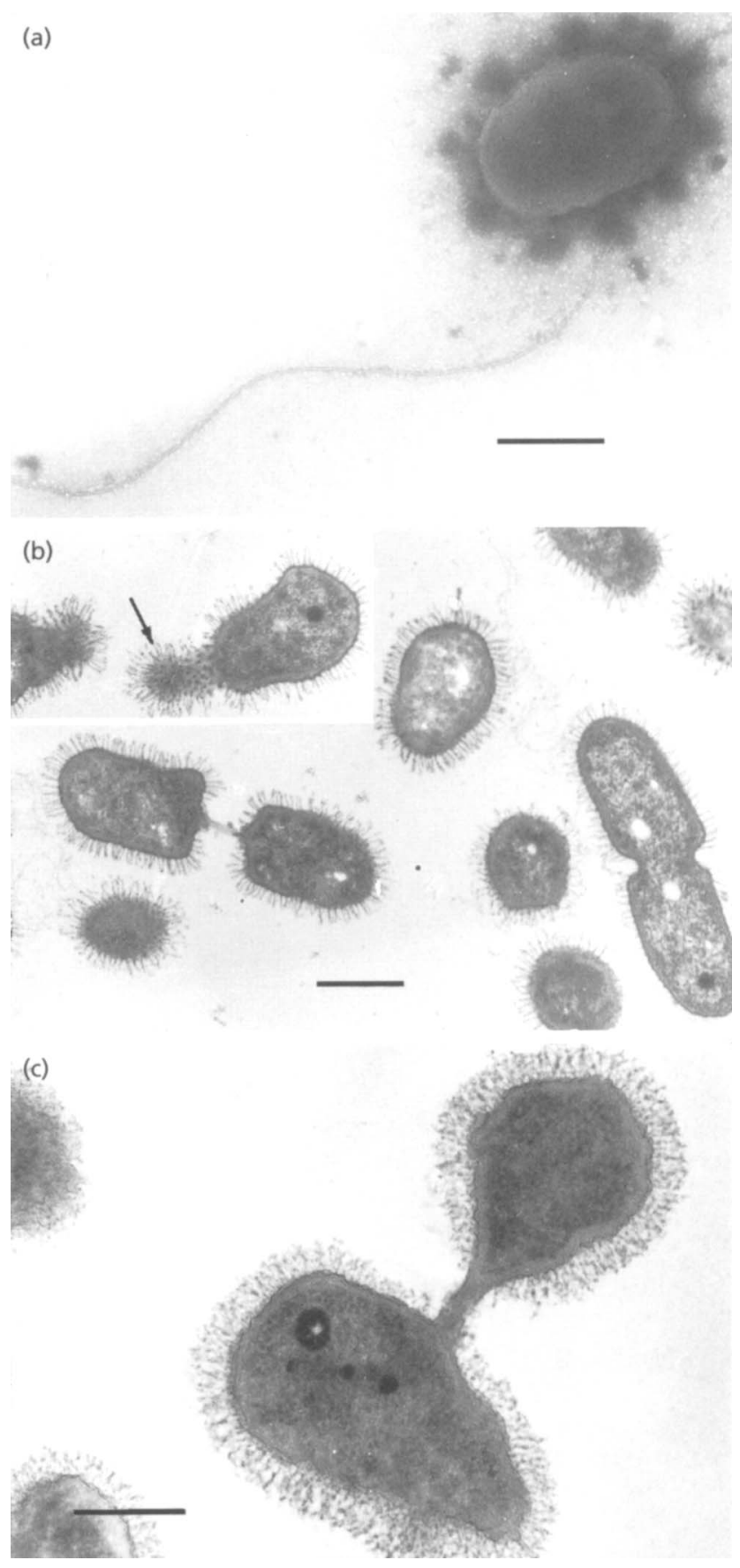

Fig. 1. Electron micrographs of cells of strain $\mid \mathrm{M} 1^{\top}$. (a) Negatively stained preparation. Note the subpolar location of the single flagellum; a large amount of capsular material is evident. ( $b, c)$ Ultrathin sections; different stages of cell division. The arrow in (b) indicates a part of the capsule covered with spikes. (c) Constrictions in the final stage of cell division. Bars, $0.5 \mu \mathrm{m}$.

$(0 \cdot 8-1 \cdot 5) \mu \mathrm{m}$ in size, with a cell shape sometimes approaching coccoid. Reproduction occurred by binary fission. The separating daughter cells were equal in size to the parent cells and had one lateral flagellum (Fig. 1a). After division, the cells remained 
Table 1. Cellular fatty acid composition of colourless and pink-pigmented serine pathway methylobacteria (\% of total fatty acids)

Bacteria were grown on agarized synthetic medium with $0.5 \%(\mathrm{v} / \mathrm{v})$ methanol or $0.3 \%(\mathrm{w} / \mathrm{v})$ methylamine for $24 \mathrm{~h}$ at $29{ }^{\circ} \mathrm{C}$.

\begin{tabular}{|c|c|c|c|c|c|c|c|c|c|c|c|}
\hline \multirow[t]{2}{*}{ Strain } & \multirow[t]{2}{*}{$\mathrm{n} 16: 0$} & \multirow[t]{2}{*}{$\sigma 16: 1^{*}$} & \multirow[t]{2}{*}{ n18:0 } & \multirow[t]{2}{*}{$c 18: 1609$} & \multirow[t]{2}{*}{$c 18: 1 \omega 7$} & \multirow[t]{2}{*}{$t 18: 1 \omega 7$} & \multirow[t]{2}{*}{ cy19:0 } & \multirow[t]{2}{*}{ cMe18:1 } & \multicolumn{3}{|c|}{ Hydroxy acids $3-\mathrm{OH} \dagger$} \\
\hline & & & & & & & & & $C_{12: 11}$ & $C_{1+: 10}$ & $C_{16: 11}$ \\
\hline $\mid \mathrm{M}]^{\mathrm{T}}$ & $5 \cdot 5$ & $0 \cdot 6$ & $4 \cdot 5$ & $1 \cdot 0$ & $68 \cdot 6$ & $7 \cdot 8$ & $8 \cdot 4$ & 1.4 & & 1.2 & \\
\hline $\mathrm{UZ}$ & 2.8 & $1 \cdot 1$ & $3 \cdot 4$ & $0 \cdot 7$ & 67.6 & 48 & $15 \cdot 1$ & $1 \cdot 3$ & & $1 \cdot 3$ & \\
\hline 14 & 3.8 & $1 \cdot 1$ & $3 \cdot 6$ & 0.7 & $65 \cdot 3$ & 6.8 & $14 \cdot 1$ & $1 \cdot 2$ & & $1 \cdot 2$ & \\
\hline Aminobacter aminovorans ATCC $23314^{\mathrm{T}}$ & $9 \cdot 8$ & $1 \cdot 2$ & $7 \cdot 6$ & $0 \cdot 6$ & $55 \cdot 7$ & $6 \cdot 5$ & $3 \cdot 1$ & 0 & $0 \cdot 4$ & & \\
\hline Methylorhabdus multivorans ATCC $51890^{\mathrm{T}}$ & $15 \cdot 4$ & $1 \cdot 8$ & $4 \cdot 0$ & 0.8 & $52 \cdot 8$ & $8 \cdot 4$ & 16.7 & $3 \cdot 1$ & & $1 \cdot 1$ & \\
\hline Methilohacterium organophilum ATCC $27886^{\mathrm{T}}$ & 2.8 & 0.4 & $7 \cdot 7$ & $0 \cdot 7$ & $76 \cdot 8$ & $9 \cdot 4$ & $0 \cdot 3$ & 0 & & $0-8$ & \\
\hline Methylobacterium extorquens NCIB $9399^{\mathrm{T}}$ & $5 \cdot 4$ & $7 \cdot 0$ & $9 \cdot 4$ & $1 \cdot 3$ & $66 \cdot 2$ & $8 \cdot 3$ & $0 \cdot 8$ & 0 & & 0.5 & \\
\hline Methylobacterium rhodesianum NCIB $10611^{\text {TP }}$ & 4.5 & 0.6 & $8 \cdot 3$ & $1 \cdot 0$ & $73 \cdot 7$ & $8 \cdot 6$ & $0 \cdot 3$ & 0 & & $1 \cdot 0$ & \\
\hline Hyphomicrobium zavarzinii IFAM ZV-622 & $4 \cdot 7$ & $0 \cdot 9$ & $8 \cdot 1$ & $0 \cdot 6$ & $80 \cdot 4$ & $5 \cdot 4$ & $5 \cdot 0$ & 0 & & $2 \cdot 3$ & 1.7 \\
\hline
\end{tabular}

* Total hexadecenoic acids shown, including palmitoleic, palmitelaidinic and 16:1 with position of double bond not established.

$\dagger$ Analysed as methoxy derivative form.

connected by a constriction apparently formed by the outer membrane (Fig. 1b,c). The bacteria studied had a distinct capsule covered with spikes (Fig. 1a).

\section{Physiological characteristics}

Colonies on glucose-potato agar ( $2 \mathrm{~d}$ ) were punctate, round, convex, lustrous, white, translucent, uniform in consistency and mucoid. Streak cultures on meatpeptone agar were distinct and white, with even edges, a smooth surface and a mucoid consistency. Growth was moderate and odourless. Growth on agarized medium with methanol was profuse, diffuse and mucoid, and the colonies had even edges and a smooth surface. The strains hydrolysed starch and gelatin (weakly), but not cellulose and casein milk, although

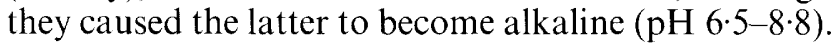
Acidification was observed on glucose-containing medium without gas formation. All strains were strict aerobes, although they reduced nitrates to nitrites slowly ( 2 weeks). They did not form indole or ammonia, but evolved hydrogen sulfide on meatinfusion broth. Methyl red and Voges-Proskauer tests were negative. No water-soluble fluorescent pigment was produced on King A and B media. Urease and oxidase were present, catalase activity was very low.

The strains grew well on mineral salt liquid medium with methanol (optimal concentration $0.5 \%$ ) or methylamine $(0.3 \%)$ as the carbon and energy sources. Additional growth factors (yeast autolysate, biotin, thiamin, nicotinic acid and riboflavin) were not required. Bacterial growth was also supported by some alcohols (ethanol, butanol, glycerol and sorbitol), organic acids (pyruvic, malic, succinic and fumaric acids), carbohydrates (maltose, glucose, fructose, sucrose and arabinose), as well as some amino acids (glutamate and sarcosine). Strains IM1 ${ }^{\mathrm{T}}$, UZ, 9AA, 10AA, 26AA and 37AA did not grow on methane, mono- and dichloromethane, citrate, methionine, asparagine, lysine, arginine, histidine, glycine, valine, betaine or under the gas mixture of $\mathrm{CO}_{2}+\mathrm{H}_{2}+\mathrm{O}_{2}$. Strain 14 also failed to grow on butanol, sorbitol and fructose, but could utilize $N, N$-dimethylglycine. All strains utilized methylamine, some amino acids, urea, peptone, ammonium salts and nitrates as nitrogen sources. The optimum growth temperature was $28-30{ }^{\circ} \mathrm{C}$, while $\mathrm{pH}$ optimum was $7 \cdot 0-7 \cdot 2$. Growth did not occur in the presence of $3 \% \mathrm{NaCl}$. The generation time was $7-12 \mathrm{~h}$ on medium $\mathrm{K}$ with $0.5 \% \mathrm{CH}_{3} \mathrm{OH}$.

\section{Chemotaxonomic characteristics}

Table 1 shows cellular fatty acid profiles for the new isolates and members of the genera Methylobacterium, Aminobacter, Methylorhabdus and Hyphomicrobium. The methylation of cis-vaccenic acid $\left(c_{18: 1 \omega i}\right)$ to lactobacillic acid $\left(\mathrm{cy}_{19: 0}\right)$ must be considered as a remarkable difference between colourless methylobacteria and the PPFMs. The virtual absence of lactobacillic acid in the fatty acid spectra of the PPFMs has also been reported by other authors (Urakami \& Komagata, 1984). Another feature of the fatty acid spectra of all the strains is the occurrence of cismethyloctadec-11-enoic acid, an isomer of lactobacillic acid which is also formed by methylation of cisvaccenic acid. This fatty acid is synthesized by some Gram-negative stalked bacteria (Prosthecomicrobium, Caulobacter, Asticaccaulis), but it is completely absent in members of the genera Methylobacterium, Aminobacter and Hyphomicrobium (Andreev et al., 1986). The PPFMs, Methylorhabdus multivorans and the new isolates contained primarily $3-\mathrm{OH} \mathrm{C} \mathrm{C}_{14: 0}$ acid, whereas Hyphomicrobium spp. contained 3-OH $\mathrm{C}_{16: 0}$ and Aminobacter strains contained large amounts of $3-\mathrm{OH}$ $\mathrm{C}_{12: 0}$ acid (Urakami et al., 1992). Remarkably, Hyphomicrobium zavarzinii had ubiquinone Q-9, while all the other serine pathway methylobacteria possessed ubiquinone Q-10.

As seen from Table 2, the major phospholipids in the serine pathway facultative methylobacteria are phosphatidylethanolamine $(12-50 \%)$ and phospha- 
Methylopila, a new genus of aerobic methylobacteria

Table 2. Phospholipid composition of colourless and pink-pigmented serine pathway methylobacteria

Abbreviations: PEA, phosphatidylethanolamine; PG, phosphatidylglycerol; DPG, diphosphatidylglycerol; PA, phosphatidic acid; PS, phosphatidylserine; PC, phosphatidylcholine; LL, lysolycetine; 8-12, unidentified phospholipids.

\begin{tabular}{|c|c|c|c|c|c|c|c|c|c|c|c|c|}
\hline \multirow[t]{2}{*}{ Strain } & \multicolumn{12}{|c|}{ Phospholipid (\%) } \\
\hline & PEA & PG & DPG & $\mathbf{P A}$ & PS & PC & $\mathbf{L L}$ & 8 & 9 & 10 & 11 & 12 \\
\hline $\mathrm{IM} 1^{\mathrm{T}}$ & 40 & 12 & 8 & 3 & 1 & 18 & 7 & 5 & 0 & 0 & 5 & 0 \\
\hline $\mathrm{UZ}$ & 42 & 11 & 8 & 3 & 0 & 17 & 6 & 4 & 0 & 0 & 6 & 0 \\
\hline 14 & 23 & 20 & 5 & 3 & 0 & 36 & 4 & 2 & 2 & 2 & 1 & 2 \\
\hline $\begin{array}{l}\text { Aminobacter aminovorans } \\
\text { ATCC } 23314^{\mathrm{T}}\end{array}$ & 37 & 16 & 10 & 2 & 0 & 25 & 1 & 1 & 2 & 0 & 5 & 3 \\
\hline $\begin{array}{l}\text { Methylorhabdus multivorans } \\
\text { ATCC } 51890^{\mathrm{T}}\end{array}$ & 24 & 13 & 4 & 1 & 0 & 43 & 2 & 2 & 2 & 1 & 3 & 3 \\
\hline $\begin{array}{l}\text { Methylobacteruim organophilum } \\
\text { ATCC } 27886^{\mathrm{T}}\end{array}$ & 12 & 21 & 5 & 2 & 1 & 47 & 6 & 2 & 0 & 1 & 1 & 1 \\
\hline Methylobacterium extorquens NCIB $9399^{\mathrm{T}}$ & 26 & 14 & 4 & 2 & 3 & 35 & 2 & 2 & 0 & 4 & 4 & 4 \\
\hline
\end{tabular}

Table 3. Enzyme activities in cell extracts of the new isolates of methylobacteria grown on different substrates

PMS, phenazine methosulfate; PEP, phosphoenolpyruvate. There was no activity with any of the following enzymes and cofactors: formaldehyde dehydrogenase $\left(\mathrm{NAD}^{+}\right)$, formate dehydrogenase (NAD $\left.{ }^{+}\right)$, isocitrate dehydrogenase $\left(\mathrm{NAD}^{+}\right)$, isocitrate lyase and pyruvate carboxylase.

\begin{tabular}{|c|c|c|c|c|c|c|}
\hline \multirow[t]{3}{*}{ Enzyme (cofactor) } & \multicolumn{6}{|c|}{ Enzyme activity [nmol min $^{-1}\left(\mathrm{mg}\right.$ protein) $\left.{ }^{-1}\right]$} \\
\hline & \multicolumn{2}{|c|}{ Strain IM1 ${ }^{\mathrm{T}}$} & \multicolumn{2}{|c|}{ Strain UZ } & \multicolumn{2}{|c|}{ Strain 14} \\
\hline & Methanol & Succinate & Methanol & Succinate & Methanol & Succinate \\
\hline Methanol dehydrogenase (PMS) & 362 & 118 & 250 & 71 & 310 & 102 \\
\hline$N$-Methylglutamate dehydrogenase (PMS) & $0^{*}$ & 0 & $0^{*}$ & 0 & $0^{*}$ & 0 \\
\hline Methylamine dehydrogenase (PMS) & $226^{*}$ & 21 & $180^{*}$ & 14 & $210^{*}$ & 22 \\
\hline Formaldehyde dehydrogenase (PMS) & 77 & 9 & 68 & 7 & 82 & 10 \\
\hline Formate dehydrogenase (PMS) & 129 & 22 & 98 & 11 & 135 & 15 \\
\hline Hydroxypvruvate reductase (NADH) & 1930 & 497 & 1910 & 329 & 2100 & 310 \\
\hline Hydroxypvruvate reductase (NADPH) & 759 & 387 & 720 & 250 & 815 & 200 \\
\hline Serine-glyoxylate aminotransferase (NADH) & 237 & 90 & 240 & 52 & 330 & 100 \\
\hline Malate lyase (ATP, CoA) & 52 & 19 & 49 & 15 & 67 & 11 \\
\hline Glycerate kinase (ATP) & 28 & 12 & 34 & 10 & 35 & 12 \\
\hline Pyruvate dehydrogenase $\left(\mathrm{NAD}^{+}\right)$ & 47 & 63 & 52 & 74 & 49 & 76 \\
\hline Citrate synthase & 10 & 35 & 15 & 55 & 11 & 65 \\
\hline Isocitrate dehydrogenase $\left(\mathrm{NADP}^{+}\right)$ & 41 & 72 & 49 & 84 & 56 & 90 \\
\hline Malate dehydrogenase (NADH) & 51 & 215 & 68 & 290 & 70 & 325 \\
\hline Malate dehydrogenase (NADPH) & 55 & 94 & 72 & 110 & 69 & 120 \\
\hline$\alpha$-Ketoglutarate dehydrogenase $\left(\mathrm{NAD}^{+}\right)$ & 8 & 14 & 8 & 17 & 10 & 21 \\
\hline Succinate dehydrogenase (PMS) & 27 & 88 & 30 & 85 & 25 & 76 \\
\hline \multicolumn{7}{|l|}{ PEP carboxylase } \\
\hline+ Acetyl-CoA & 88 & 31 & 85 & 28 & 90 & 27 \\
\hline -Acetyl-CoA & 39 & 19 & 35 & 15 & 42 & 15 \\
\hline
\end{tabular}

* Methylamine-grown cells.

tidylcholine (17-47\%). Strains IM1 ${ }^{\mathrm{T}}$, UZ, 14, 9AA, 26AA and 34AA have been shown (Trotsenko et al., 1993) to accumulate a large amount of poly- $\beta$ - hydroxybutyrate (20-40\%, dry cell weight) under nitrogen limitation and excess of carbon source (methanol). 
N. V. Doronina and others

Table 4. DNA-DNA relatedness between colourless and pink-pigmented serine pathway methylobacteria

\begin{tabular}{|c|c|c|c|c|c|c|}
\hline \multirow[t]{2}{*}{ Strain } & \multicolumn{6}{|c|}{ Hybridization (\%) with labelled DNA from strains: } \\
\hline & IM1 $^{\mathbf{T}}$ & $\mathbf{U Z}$ & ATCC 23314 & ATCC 51890 & ATCC 27886 & NCIB 9399 \\
\hline $\mathrm{IM} 1^{\mathrm{T}}$ & 100 & 78 & 5 & 5 & 4 & 4 \\
\hline $\mathrm{UZ}$ & 83 & 100 & 5 & 5 & 3 & 3 \\
\hline 14 & 80 & 88 & 6 & 4 & 3 & 4 \\
\hline 9AA & 78 & 76 & 6 & 5 & 3 & 3 \\
\hline $10 \mathrm{AA}$ & 86 & 81 & 5 & 5 & 3 & 3 \\
\hline $26 \mathrm{AA}$ & 80 & 78 & 4 & 5 & 3 & 3 \\
\hline $37 \mathrm{AA}$ & 80 & 82 & 5 & 5 & 3 & 3 \\
\hline Aminobacter aminovorans ATCC $23314^{\mathrm{T}}$ & 4 & 4 & 100 & 4 & 3 & 3 \\
\hline Methylorhabdus multivorans ATCC $51890^{\mathrm{T}}$ & 5 & 5 & 5 & 100 & 4 & 3 \\
\hline Methylobacterium organophilum ATCC $27886^{\mathrm{T}}$ & 5 & 4 & 5 & 4 & 100 & 16 \\
\hline Methylobacterium extorquens NCIB $9399^{\mathrm{T}}$ & 5 & 5 & 4 & 3 & 15 & 100 \\
\hline Hyphomicrobium zavarzinii IFAM ZV-622 & 4 & 4 & 4 & 4 & 3 & 3 \\
\hline
\end{tabular}

\section{Metabolic characteristics}

To establish the routes for primary and intermediary metabolism in our isolates, the enzyme activities were determined in extracts of cells grown on methanol, methylamine or succinate. Since similar results were obtained for all the isolates tested the enzyme activities are presented for only three strains. As shown in Table 3 they oxidize methanol and methylamine to $\mathrm{CO}_{2}$ through formaldehyde and formate by the appropriate dehydrogenases active with phenazine methosulfate (PMS). The enzymes of the $N$-methylglutamate pathway were not detected. The serine pathway specific enzymes (hydroxypyruvate reductase and serineglyoxylate aminotransferase) were found. Due to the absence of the isocitrate lyase (ICL) activity the strains consequently employed the ICL-negative variant of the serine pathway. Alternatively, the key enzymes of the ribulose monophosphate and ribulose bisphosphate pathways, i.e. 3-hexulose phosphate synthase, ribulose bisphosphate carboxylase and phosphoribulokinase were not present. The new isolates had low or zero activities for the pentose phosphate pathway enzymes (glucose-6-phosphate and 6-phosphogluconate dehydrogenases as well as 2-keto-3-deoxy-6-phosphogluconate aldolase). However, they contained a complete set of enzymes of the tricarboxylic acid cycle playing primarily a biosynthetic role during methylotrophic growth. $\mathrm{CO}_{2}$ was fixed by phosphoenolpyruvate carboxylase stimulated by acetyl-CoA. Pyruvate carboxylase was absent.

\section{Genomic characteristics}

The $\mathrm{G}+\mathrm{C}$ contents of the DNA of strains IM $1^{\mathrm{T}}$, UZ, $14,9 \mathrm{AA}, 10 \mathrm{AA}, 26 \mathrm{AA}$ and $37 \mathrm{AA}$ were estimated via melting point $\left(T_{\mathrm{m}}\right)$ as $66 \cdot 5-69 \cdot 2 \mathrm{~mol} \%$. Because DNA hybridization remains the optimal method for measuring the degree of relatedness between highly related organisms (Stackebrandt \& Goebel, 1994), the degree of genomic similarity between the strains and members of the other taxa was assessed by DNA-DNA hybridization (Table 4). The DNA hybridization values among the new strains were very high (76-90\%), making it possible to assign all of them to the same taxonomic cluster (genus and species). On the other hand, they had a low degree of DNA hybridization with the representatives of the genera Methylobacterium, Aminobacter, Hyphomicrobium, Methylorhabdus and Pseudomonas.

\section{Comparative sequence analysis}

The 1331 nucleotides of the strain IM1 ${ }^{\mathrm{T}}$ 16S rRNA gene were sequenced, corresponding to positions 81406 of the $E$. coli sequence. The phylogenetic analysis employing different algorithms showed similar results. The branching pattern of the methylotrophic strains correlated perfectly with previous results of Bratina et al. (1992) and Janvier \& Grimont (1995). According to our data strain $I M 1^{\mathrm{T}}$ appears to be related to the members of the $\alpha$-subclass of Proteobacteria. The affiliation of this strain to the $\alpha$-subclass is supported by signature analysis. Some features characteristic for the $16 \mathrm{~S}$ rDNA molecule of the $\alpha$-subclass, such as a shortened helix in nucleotide positions 184-193 (E. coli numbering) and all specific signature positions (Woese, 1987) were found in the sequences analysed.

The matrix of full sequence similarity values for strain $\mathrm{IM} 1^{\mathrm{T}}$ and representative members of the Proteobacteria indicate that for strain $\mathrm{IM}^{\mathrm{T}}$ the highest degree of relationship is found with certain members of the $\alpha-2$ subclass, e.g. Xanthobacter agilis $(92 \cdot 5 \%$ similarity) and Brucella abortus ( $92.7 \%$ similarity). These values, however, are not necessarily an indication of specific relationship with these organisms, because they belong to different clusters of the $\alpha-2$ subclass of Proteobacteria. In the unrooted tree constructed (data not shown), strain $I M 1^{\mathrm{T}}$ forms a 


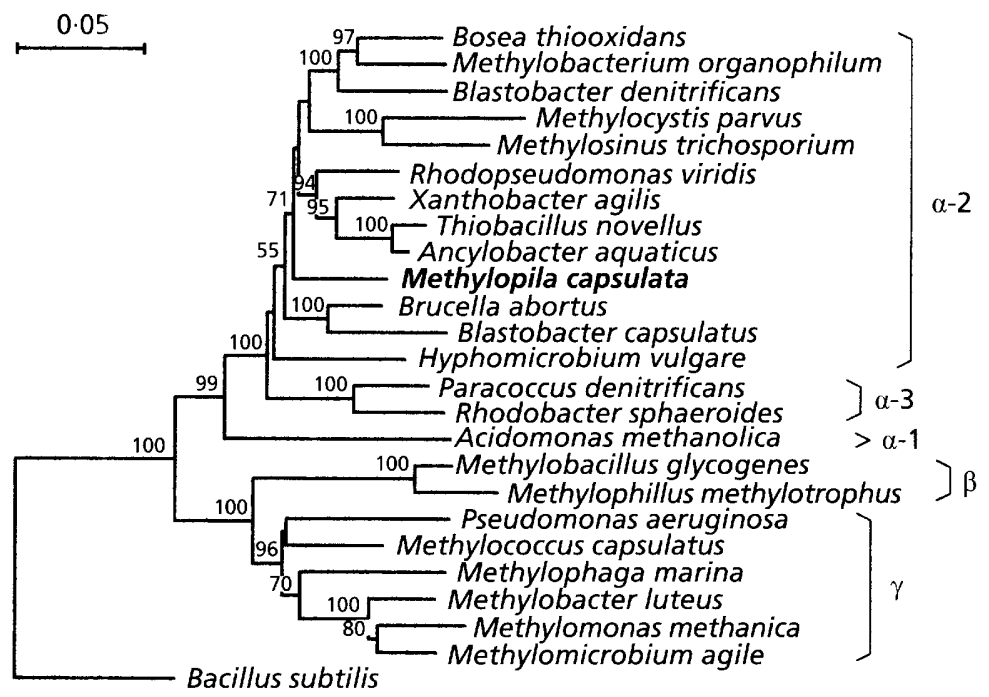

Fig. 2. Rooted-by-outgroup phylogenetic
tree showing relationships among
Methylopila capsulata strain IM $1^{\top}$ and other
members of the Proteobacteria including
methylotrophic genera. Bacillus subtilis is
the outgroup. Numbers refer to bootstrap
values (more than 50). Bar indicates a
distance of 0.05 .

separate branch within the $\alpha-2$ subclass. In the rootedby-outgroup tree (Fig. 2), the bootstrap value is too low (Woese, 1987) for the branching point of strain $\mathrm{IM} 1^{\mathrm{T}}$. Hence, strain $\mathrm{IM} 1^{\mathrm{T}}$ is a new branch of the $\alpha-2$ subclass of Proteobacteria.

\section{DISCUSSION}

The new isolates were distinguished clearly from members of the genus Pseudomonas sensu stricto, on the basis of the following characteristics: utilization of $\mathrm{C}_{1}$-compounds (methanol and methylated amines), quinone system, cellular fatty acid composition (Urakami et al., 1992), and low level of DNA-DNA hybridization. As mentioned above, only four generic names have been validly published for Gram-negative serine pathway methylobacteria: Methylobacterium (Patt et al., 1976), Aminobacter (Urakami et al., 1992), Hyphomicrobium (Hirsch, 1984), and Methylorhabdus (Doronina et al., 1995). However, our isolates differed from the PPFMs belonging to the genus Methylobacterium by some morphological features, colour of colonies, hydrolysis of gelatin and starch, cellular fatty acid composition and low DNA similarity. The new strains were distinguished from non-pigmented members of the genus Aminobacter by methanol utilization, primary $\mathrm{C}_{1}$-metabolism, cellular fatty acid composition, DNA $\mathrm{G}+\mathrm{C}$ content and low DNA similarity levels. They also differed from members of the genus Hyphomicrobium by their inability to form hyphae, quinone system, primary methylamine metabolism, cellular fatty acid composition and low DNA similarity and from Methylorhabdus multivorans by morphological features, the presence of oxidase and low DNA similarity. Based on these results, our isolates are close neighbours and might be placed in a separate taxon, for which we propose the generic name Methylopila, with the type species Methylopila capsulata. The major characteristics differentiating the genus Methylopila from the other related genera of serine pathway methylobacteria are summarized in Table 5.

The results of our $16 \mathrm{~S}$ rDNA sequence analysis showed that the genus Methylopila forms a distinct branch within the $\alpha$-subclass of the Proteobacteria, separated from known genera of aerobic methylotrophic bacteria. Phylogenetic relationships that were derived from the $16 \mathrm{~S}$ rDNA sequence analysis correlate well with the results of 5S rDNA sequencing (Boulygina et al., 1993). Genotypic data also demonstrated that a new genus was clearly separated from all other described taxa of the serine pathway methylobacteria. On the basis of the data presented here and that published previously by Govorukhina et al. (1989) we propose that the seven isolates studied be placed in a new genus, for which we propose the name Methylopila gen. nov. The genus contains a single species, which is automatically the type species of the genus. The strains, currently placed within the genus Methylopila were originally described under the name 'Methylomicrobium capsulatum' (Govorukhina et al., 1989), and we therefore propose that the new species be named Methylopila capsulata sp. nov.

\section{Description of the genus Methylopila gen. nov.}

Methylopila (Me.thyl.o.pi.la. M.L.n. methyl the methyl group; Gr. adj. pila ball or sphere; M.L. Methylopila methyl-using sphere).

When grown on methanol mineral salt medium, the cells are motile rods, usually $0.5-0.7 \mu \mathrm{m}$ in diameter and $1.0-1.3 \mu \mathrm{m}$ in length, which occur singly or in pairs. Gram-negative. Non-pigmented. Endospores are absent. Multiply by fission. No prosthecae detected. Colonies are white. Pyocyanin and fluorescein are not produced. Growth is supported by nutrient agar and PYG agar. The methyl red and Voges-Proskauer tests are negative. Oxidase- and urease-positive. Acids are produced from sugars 
Table 5. Major differentiating characteristics of the serine pathway facultative methylobacteria belonging to various genera

\begin{tabular}{|c|c|c|c|c|c|}
\hline Character & Methylobacterium & Aminobacter & Hyphomicrobium & Methylorhabdus & Methylopila \\
\hline Morphology (flagella) & + & + & + & - & + \\
\hline \multicolumn{6}{|l|}{ Reproduction by: } \\
\hline Budding & - & + & + & - & - \\
\hline Division & + & - & - & + & + \\
\hline Hyphae formation & - & - & + & - & - \\
\hline Oxidase & + & + & - & - & + \\
\hline Catalase & + & + & + & + & - \\
\hline Carotenoids & + & - & - & - & - \\
\hline \multicolumn{6}{|l|}{ Methylamine metabolism: } \\
\hline Amine dehydrogenase & + & - & - & + & + \\
\hline$N$-Methylglutamate & + & + & + & - & - \\
\hline $\begin{array}{l}\text { Formaldehyde dehydrogenase } \\
\left(\mathrm{NAD}^{+} / \mathrm{GSH}\right)\end{array}$ & - & - & - & + & - \\
\hline Isocitrate lyase & - & + & + & - & - \\
\hline Cyclopropane acid $\mathrm{cy}_{19: 0}$ & Trace & + & + & + & + \\
\hline Major ubiquinone & Q-10 & Q-10 & Q-9 & Q-10 & Q-10 \\
\hline Utilization of methanol & + & - & + & + & + \\
\hline DNA $G+C$ content $(\mathrm{mol} \%)$ & $60-70$ & $62-64$ & $61-65$ & $66-67$ & $66-70$ \\
\hline
\end{tabular}

oxidatively, but not fermentatively. Nitrates are reduced to nitrites slowly. Chemo-organotrophic and facultatively methylotrophic assimilating $\mathrm{C}_{1}$ compounds by the isocitrate lyase ${ }^{-}$serine pathway. Vitamins are not required for growth. Ammonium salts, nitrate, urea, peptone, some amino acids and methylated amines are utilized as nitrogen sources. Strictly aerobic, with respiratory metabolism. Good growth occurs between $\mathrm{pH} 6.5$ and 7.5 , but not above pH 9.0 and below pH 5.0. Grows well at 28 and $35^{\circ} \mathrm{C}$ but not at $42{ }^{\circ} \mathrm{C}$. No growth in the presence of $3 \%$ $\mathrm{NaCl}$. The cell fatty acid profile is characterized by the presence of $60-70 \%$ cis-vaccenic acid $\left(c_{18: 1 \omega 7}\right)$. The major hydroxy acid is $3-\mathrm{OH} \mathrm{C} \mathrm{C}_{14: 0}$. The quinone system is ubiquinone Q-10. Dominant phospholipids are phosphatidylethanolamine and phosphatidylcholine. The DNA G + C content ranges from 66 to $70 \mathrm{~mol} \%$. The levels of DNA-DNA hybridization with members of the genera Methylorhabdus, Methylobacterium, Aminobacter, Hyphomicrobium and Pseudomonas are less than $10 \%$. The genus Methylopila belongs to the $\alpha-2$ subclass of the Proteobacteria, as revealed by comparative sequence analysis of the $16 \mathrm{~S}$ rDNA, and is phylogenetically distinct from the other methylotrophic genera. The type species is Methylopila capsulata.

\section{Description of Methylopila capsulata sp. nov.}

Methylopila capsulata (cap.su.la'ta. L.n. capsule a small chest, capsule; M.L. adj. capsulata having a capsule).

In addition to the characteristics that define the genus, it has the characteristics described below. Cells are motile pleomorphic rods or cocci occurring singly or in pairs and having a capsule covered with spikes. Colonies grown on nutrient agar or glucose-potato agar are round; viscous, semitransparent, convex, even edged, $2 \mathrm{~mm}$ in diameter. Cells accumulate poly- $\beta$ hydroxybutyrate. Does not form indole or $\mathrm{NH}_{3}$. Catalase activity is very low. Produce $\mathrm{H}_{2} \mathrm{~S}$ during growth in nutrient broth. Utilizable carbon sources are methanol, methylated amines, butanol, ethanol, glycerol, maltose, sucrose, L-arabinose, D-fructose, Dglucose, succinate, fumarate, pyruvate. Gelatin and starch are hydrolysed weakly. Methanol and methylamine are oxidized by the appropriate PMS-linked dehydrogenases to formaldehyde which is assimilated by the isocitrate lyase ${ }^{-}$serine pathway. The mol\% $\mathrm{G}+\mathrm{C}$ of the DNA is $67 \cdot 2\left(T_{\mathrm{m}}\right)$. The type strain $\mathrm{IM}^{\mathrm{T}}$ was isolated from soil of Tashkent city (Uzbekistan) and is deposited in the Russian Collection of Microorganisms as Methylopila capsulata VKM B-1606 ${ }^{\mathrm{T}}$. The species also includes strains UZ, 14, 9AA, 10AA, 26AA and 37AA.

\section{ACKNOWLEDGEMENTS}

The authors are indebted to the referees for valuable comments on the manuscript. This work was financially supported by the RFBR grants 96-04-50820 and 98-0448144.

\section{REFERENCES}

Andreev, L. B., Akimov, V. N. \& Nikitin, D. I. (1986). Peculiarities of fatty acid composition of the genus Caulobacter. Folia Microbiol 31, 144-153.

Boulygina, E. S., Chumakov, K. M. \& Netrusov, A. I. (1993). Systematics of gram-negative methylotrophic bacteria based on $5 \mathrm{~S}$ rRNA sequences. In Microbial Growth on $C_{1}$ Compounds, pp. 
275-284. Edited by J. C. Murrell \& D. P. Kelly. Andover Intercept.

Bousfield, I. J. \& Green, P. N. (1985). Reclassification of bacteria of the genus Protomonas Urakami and Komagata 1984 in the genus Methylobacterium (Patt, Cole and Hanson) emend. Green and Bousfield 1983. Int J Syst Bacteriol 35, 209.

Bowman, J. P., Sly, L. I. \& Stackebrandt, E. S. (1995). The phylogenetic position of the family Methylococcaceae. Int $J$ Syst Bacteriol 45, 182-185.

Bratina, B. J., Brusseau, G. A. \& Hanson, R. S. (1992). Use of $16 \mathrm{~S}$ rRNA analysis to investigate phylogeny of methylotrophic bacteria. Int J Syst Bacteriol 42, 645-648.

Braunegg, G., Sonnleitner, B. \& Lafferty, R. M. (1978). A rapid gas chromatographic method for the determination of poly- $\beta$ hydroxybutyric acid in microbial biomass. Eur J Appl Microbiol Biotechnol 6, 29-37.

Brodsky, L. I., Drachev, A. L., Tatuzov, R. L. \& Chumakov, K. M. (1991). GeneBee: package of programs for biopolymers sequence analysis. Biopolym Cell 7, 10-14

Chumakov, K. M. \& Yushmanov, S. V. (1988). Maximum topological similarity principle in molecular systematics. Mol Genet Mikrobiol lirusol 3, 3-9 (in Russian).

Collins, M. D. (1985). Analysis of isoprenoid quinones. Methods Microbiol 18, 329-366.

Doronina, N. V. \& Trotsenko, Y. A. (1992). Methylomicrobium a new genus of non-pigmented facultatively methylotrophic bacteria. In Microbial Growth on $C_{1}$-Compounds. Abstracts of the 7th International Symposium, Warwick, UK, P.C101.

Doronina, N. V., Govorukhina, N. I., Lysenko, A. M. \& Trotsenko, Y. A. (1987). Analysis of DNA-DNA homologies in obligate methylotrophic bacteria. Microbiology (English translation of Mikrobiologiya) 57, 509-513.

Doronina, N. V., Braus-Stromeyer, S. A., Leisinger, T. \& Trotsenko, Y. A. (1995). Isolation and characterization of a new facultatively methylotrophic bacterium: description of Methylorhabdus multivorans, gen nov., sp.nov. Syst Appl Microbiol 18, 92-98.

Govorukhina, N. I., Doronina, N. V., Andreev, L. V. \& Trotsenko, Y. A. (1989). Methylomicrobium: a new genus of facultatively methylotrophic bacteria. Microbiology (English translation of Mikrobiologiva) 58, 260-266.

Govorukhina, N. I. \& Trotsenko, Y. A. (1989). Phospholipid composition of methylotrophic bacteria. Microbiology (English translation of Mikrobiologiva) 58, 318-323

Hirsch, P. (1984). Genus Hyphomicrobium Stutzer and Hartleb 1898. In Bergey's Manual of Determinative Bacteriology, 9th edn, pp. 1895-1904. Edited by R. E. Buchanan \& N. E. Gibbons. Baltimore: Williams \& Wilkins.

Janvier, M. \& Grimont, P. A. D. (1995). The genus Methylophaga, a new line of descent within phylogenetic branch $\gamma$ of Proteobacteria. Res Microbiol 146, 543-550.
Jukes, T. H. \& Cantor, C. R. (1969). Evolution of protein molecules. In Mammalian Protein Metabolism, vol. 3, pp. 21-132. Edited by H. N. Munro. New York: Academic Press.

Lane, D. J. (1991). 16S/23S rRNA sequencing. In Nucleic Acid Techniques in Bacterial Systematics, pp. 115-147. Edited by E. Stackebrandt \& M. Goodfellow. New York: Wiley.

Larsen, N., Olsen, G. J., Maidak, B. L., McCaughey, M. J., Overbeek, R., Macke, T. J., Marsh, T. L. \& Woese, C. R. (1993). The ribosomal database project. Nucleic Acid Res 21, 3021-3023.

Marmur, J. A. (1961). A procedure for the isolation of deoxyribonucleic acid from microorganisms. $J \mathrm{Mol}$ Biol 3, 208-214.

Meiberg, J. B. M. \& Harder, W. (1978). Aerobic and anaerobic metabolism of trimethylamine, dimethylamine and methylamine in Hyphomicrobium X. J Gen Microbiol 106, 265-276.

Owen, R. J. \& Lapage, S. P. (1976). The thermal denaturation of partly purified bacterial deoxyribonucleic acid and its taxonomic applications. J Appl Bacteriol 41, 335-340.

Patt, T. E., Cole, G. C. \& Hanson, R. S. (1976). Methylobacterium, a new genus of facultatively methylotrophic bacteria. Int J Syst Bacteriol 26, 226-229.

Saitou, N. \& Nei, M. (1987). The neighbor-joining method: a new method for reconstructing phylogenetic trees. Mol Biol Evol 4, 406425 .

Stackebrandt, E. \& Goebel, B. M. (1994). Taxonomic note: a place for DNA-DNA reassociation and $16 \mathrm{~S}$ RNA sequence analysis in the present species definition in bacteriology. Int $J$ Syst Bacteriol 44, 846-849.

Trotsenko, Y. A., Doronina, N. V. \& Govorukhina, N. I. (1986). Metabolism of non-motile obligately methylotrophic bacteria. FEMS Microbiol Lett 3, 293-297.

Trotsenko, Y. A., Doronina, N. V., Sokolov, A. P. \& Ostafin, M. (1993). PHB synthesis by methane and methanol-utilizing bacteria. In Proceedings of the International Symposium on Bacterial Polyhydroxyalkanoates, pp. 393-394. Edited by H. G. Schlegel \& A. Steinbuchel. Gottingen: Goltze-Druck.

Urakami, T. \& Komagata, K. (1984). Protomonas, a new genus of facultatively methylotrophic bacteria. Int $J$ Syst Bacteriol 34, 188-201.

Urakami, T., Araki, H., Uyanagi, H., Suzuki, K.-I. \& Komagata, K. (1992). Transfer of Pseudomonas aminovorans (den Dooren de Jong 1926) to Aminobacter gen. nov. as Aminobacter aminovorans comb. nov. and description of Aminobacter aganoensis sp. nov. and Aminobacter niigataensis sp. nov. Int $J$ Syst Bacteriol 42, 84-92.

Van de Peer, V. \& De Wachter, R. (1994). TREECON for Windows a software package for the construction and drawing of evolutionary trees for the Microsoft Windows environment. Comput Appl Biosci 10, 569-570.

Woese, C. R. (1987). Bacterial evolution. Microbiol Rev 51, 221-271. 
